\title{
London School of Economics
}

\section{The Suntory and Toyota International Centres for Economics and Related Disciplines}

The Bryce Conference on the Reform of the House of Lords

Author(s): H. B. Lees-Smith

Source: Economica, No. 6 (Oct., 1922), pp. 220-227

Published by: Wiley on behalf of The London School of Economics and Political Science and The Suntory and Toyota International Centres for Economics and Related Disciplines Stable URL: http://www.jstor.org/stable/2548315

Accessed: 26-06-2016 01:40 UTC

Your use of the JSTOR archive indicates your acceptance of the Terms \& Conditions of Use, available at

http://about.jstor.org/terms

JSTOR is a not-for-profit service that helps scholars, researchers, and students discover, use, and build upon a wide range of content in a trusted digital archive. We use information technology and tools to increase productivity and facilitate new forms of scholarship. For more information about JSTOR, please contact support@jstor.org.

London School of Economics, Wiley, The Suntory and Toyota International Centres for Economics and Related Disciplines, The London School of Economics and Political Science are collaborating with JSTOR to digitize, preserve and extend access to Economica 


\title{
The Bryce Conference on the Reform of the House of Lords
}

\author{
By H. B. LeEs-Smith, \\ Department of Political Science, London School of Economics.
}

THE resolutions for the Reform of the House of Lords, which have been foreshadowed in the King's Speech for the last three years, were introduced into the House of Lords on July 18th of this year. A large number of the leading peers expressed their preference for the scheme worked out by the Bryce Conference. An account of this Conference may, therefore, be of use to those who intend to follow the future discussions upon the subject.

The "Conference on the Reform of the Second Chamber" was set up by the Prime Minister in 1917. It consisted of thirty members, drawn from both Houses of Parliament and from all parties, with Viscount Bryce as the Chairman. Its discussions cover a survey of practically every device proposed for the solution of the Second Chamber problem. The Conference published no evidence or detailed record of its proceedings. But I have had access to its minutes and memoranda which, without including anything of a confidential nature, afford the material for the following article.

The thirty members of the Conference included all opinions, from the leading champions of the House of Lords in the contest over the Parliament Act to advocates of the single-chamber system. The hope that this body would reach unanimous conclusions was soon seen to be unattainable. No report, therefore, was issued, but a letter was written by the Chairman, Lord Bryce, to the Prime Minister, indicating the course of the discussions and stating that, while conclusions had been reached on many points, they weie those of a majority only. Individual members, therefore, were not bound to all recommendations, although prepared to acquiesce in the scheme as conveying what proved to represent the general view of the Conference as a whole.

Although the Conference itself was unable to follow a fully systematic order in its discussions, the development of opinion within it can be best followed by examining first the proposals for the constitution of the new Second Chamber and then those for the powers which this Chamber is to exercise.

At the beginning of the discussions, it was agreed that the existing House of Lords should select only a minority of the Second Chamber, and that, in order that the remainder of the Chamber should not contain any element of privilege, no property qualification should 
be needed either for its members or its electors. The discussions as to how the bulk of the Chamber should be selected opened with suggestions including, as might be expected, all the main schemes that exist either in the Dominions or foreign countries. These suggestions fell into four main classes:

I. Direct election by large constituencies on the plan of the Australian Senate and that of the new Legislative Council of New Zealand.

2. Nomination-for a small proportion of the Chamber-in order to secure the presence of persons of eminence not actively concerned in party politics.

3. Election by Local Authorities grouped together in geographical areas, on some such plan as that suggested by the French Senate.

4. Election by the House of Commons.

The first of these plans-that for direct election-receded into the background at an early stage of the discussions. The first principle that was generally accepted by the Conference was that the Second Chamber should not possess co-equal powers with the House of Commons, and in particular should not exercise direct control over the Executive Government with the power of making and unmaking ministries. This principle ruled out a directly elected Second Chamber, which it was felt would tend to become a rival of the House of Commons and be able logically to claim co-ordinate authority. It was also urged that large constituencies would add to the expense and labour of elections. It therefore became clear, before half the sittings had been held, that a majority of the Conference was opposed to all proposals in this direction.

The second suggestion, that of nomination-for at any rate a small element of the Chamber-had at one time the support of a clear majority of the Conference, in the hope that distinguished persons not closely connected with politics could in this way be selected. But it was pointed out that literary and scientific distinction do not specially qualify their possessors for the exercise of political power, and that, as such nominations would be made on the advice of the Prime Minister, they would be mainly utilized to reward party services. This proposal, therefore, disappeared, and the Conference turned to the two remaining methods, both involving indirect election.

Suggestions for election by Local Authorities had been before the House of Lords for a generation. ${ }^{1}$ The main scheme in which this proposal came before the Conference was that the election for each area should be in the hands of electoral colleges consisting of representatives from the Local Authorities of that area, on a plan some-

1 See Lord Rosebery's proposals, House of Lords Debates, March I9th, I 888 ; and Lord Dunraven's House of Lords Reform Bill, introduced March 23rd, 1888 . 
what similar to that adopted for the French Senate. It was, however, objected that Local Authorities are not elected with the idea of fulfilling such a purpose, and that to obtrude it into their duties would be to intensify political partisanship on issues which ought to be decided on other grounds. Liberal and Labour members of the Conference pointed out that such a plan would be unfair to them as County Councils are well known to be conservative assemblies, even in areas where the parliamentary representation is in the hands of the other parties. Behind these contentions was the belief of many members of the Conference that a Second Chamber so elected would claim to be as representative as the House of Commons, and would attempt to rival its authority. The general result was that the majority of the Conference soon made their opposition to the proposal clear, even in the modified form of combination with election by the House of Commons. By a process of exhaustion, therefore, the Conference found itself left with the fourth plan, on which its main scheme was finally based.

The election of the Second Chamber by the members of the first is the chief contribution to the solution of the problem of the relations between the two Houses which political inventiveness has made during recent years. It was suggested by Lord Rosebery to the House of Lords in 1888 as a possible means of electing a small number of members. ${ }^{1}$ Its merits are that it creates a Second Chamber which has no claim to become a rival to the first, and that it avoids the expense, labour and confusion of a second series of popular elections. On the other hand, an equally obvious result is that it is certain to be elected on party lines, to reflect the prevailing composition of parties in the Lower House, and to be largely used as a consolation for politicians who have grown tired or who have been defeated in the election for the more popular Chamber. This partisan character is an inevitable feature of every Second Chamber, however constituted, but it so impressed a number of members of the Conference that a great part of the time of the Conference was expended in attempts to discover some device by which it could be corrected.

The most obvious method was to put the election into the hands of some further body, which, while representing the general sense of the House of Commons, would be freer from party influences. The Speaker was first proposed for this purpose, and when this was seen to be impracticable, there was substituted a small Committee of Selection of about twenty members, half to be appointed by the House of Commons and half by the new Second Chamber. The objection to such a proposal-which secured its defeat by the Conference, is that a Second Chamber mainly chosen by only twenty persons, who would not themselves be directly representative of the electorate, would command so little public confidence that probably it could not be brought into existence, and certainly it could not be

\footnotetext{
1 House of Lords Debates, March I9th, I888.
} 
given any effective authority. Nevertheless, a certain number of members of the Conference were so convinced of the vital necessity of this provision that they insisted that, in the letter embodying the conclusions of the Conference, their names and opinion should be placed on record. ${ }^{1}$

The Conference thus came finally to direct election by the House of Commons ; but, in order to prevent the party with a majority from electing a Second Chamber made up of a solid block of its own supporters, it was agreed without dissent that the election should be by Proportional Representation. This, however, would have necessitated that each member of the House of Commons should have had as many votes as there were representatives to be elected, and that he should place in order of preference dozens or even hundreds of names - a task which would not only be impracticably cumbersome, but would enable a very small combination of voters to secure the quota needed to elect a member. To avoid this, the Conference decided, by a substantial majority, to divide Great Britain into thirteen areas, and to vest the election of the representatives for that area in the hands of the members of the House of Commons sitting for constituencies within the area. An additional consequence which follows from this scheme is that the power of the party Whips will be to some extent counteracted by the influences of territorial sentiment.

The character of the Second Chamber will be profoundly affected by the length of life for which its members are chosen. Opinions in the Conference ranged from those who wished it to be elected by each House of Commons for the lifetime of that House of Commons alone-the plan adopted in Norway, and, since the Conference met, in the new Parliament for Northern Ireland-to those who wished it to be elected for twelve years. The objection urged to the first proposal was that the Second Chamber would become no more than a duplicate of the House of Commons, while the opponents of the longer periods argued that it would produce a Chamber selected on issues which had long passed from the stage, and out of touch with living public opinion. The proposal for a life of twelve years finally carried the day ; and this plan, if it is carried out, will establish the longest-lived Chamber in the British Commonwealth. It was also decided that, in accordance with the usual practice of other constitutions, there should not at any time be an election for all the seats in the Second Chamber simultaneously, but that one-third of its members should be re-elected every four years.

The question of the retention in the new Second Chamber of a representation from the existing peerage raised the widest divergence of opinion, one section objecting to any such element at all, the others insisting that the House of Lords would not assent to any

1 They consisted of Lords Lansdowne, Loreburn, Balfour of Burleigh, Dunraven, Sydenham and Lord Hugh Cecil. 
scheme which did not by this means provide for the maintenance of the historic continuity of the constitution. The final settlement, carried by a majority of the Conference, was that one-quarter of the Second Chamber, i.e., eighty-one members, should be chosen from the existing peerage in the first instance, and that this number should by a gradual process be reduced to thirty.

The problem next arose of how this section of the Second Chamber should be elected. Proposals were made that it should be chosen on the same plan as the rest of the Second Chamber, that is, by members of the House of Commons. It was, however, finally decided to vest the election in a joint Committee of ten members, five to represent the new Second Chamber, chosen by the Committee of Selection of that Chamber, and five to represent the House of Commons, chosen by the Speaker. It must be noticed that, as the number of peers is reduced from eighty-one to thirty, the places thus left vacant are still to be filled by the Committee of ten, but that their choice is not restricted to the peerage. The final result, therefore, is that one-quarter of the new Second Chamber is to be selected by ten persons who are themselves the product of a process of tertiary election.

\section{DEFINITION OF A MONEY BILL}

The Conference accepted the principle that the new Second Chamber, like the present House of Lords, should have no power over Money Bills. But at this point there arises the question of " tacking " which, while appearing at first sight to be mainly a technical one, profoundly affects the future of sound legislation. What is a Money Bill? May a Labour Government carry through a socialistic programme in a series of Money Bills and so defeat the opposition of the Second Chamber? The many hours that the Conference devoted to this subject indicate the fundamental issues that it raises.

The present position, as it has been left by the Parliament Act, is that the term Money Bill is very strictly defined and that the decision as to whether a Bill comes within that definition is left to the Speaker. This provision of the Parliament Act had been fiercely resisted as it passed through the House of Commons and the issue was again raised at the Conference. Protracted discussion proved that it is beyond the wit of man to frame an inclusive and satisfactory definition of a Money Bill, and the solution of the difficulty was sought by creating a tribunal to whom each case could be referred as it arose. The Judicial Committee of the Privy Council had been frequently suggested as the most suitable tribunal, when the Parliament Act was being debated, and this proposal was repeated at the Conference. But it was argued that the decisions would not involve the interpretation of Bills, but their broad political and social effects, and that for such a purpose a parliamentary body was more suitable than alegal one. The Conference, therefore, decided that a Finance Committee, consisting of about seven members from 
each House-chosen at the beginning of each Parliament-should take the place of the Speaker as the arbiter of what constitutes a Money Bill. This proposal reappears as the fourth of the Government resolutions, with the addition that the Speaker is to be the ex-officio Chairman of the Committee. It is based upon the belief that the Speaker of the House of Commons cannot be accepted as an impartial tribunal in these disputes. But the real parties to such disputes are not the two Houses but the various political parties, and the impartiality of the Speaker in party conflicts is one of the most unquestioned traditions of our parliamentary system. This tradition has been already reflected in his attitude to Money Bills, on which he has insisted upon the strictest possible interpretation of what the term contains. In the sessions of IgII and I9I4-I6 he refused his certificate to the Finance Bills, which accordingly went up to the House of Lords as ordinary Bills. It is not reasonable to expect that - after a party fight over a Bill - a body consisting of those who are themselves partisans engaged in conflict will be more impartial than the Speaker.

When the Conference turned to the second of the chief issues which had to be decided-the general powers which the Second Chamber was to wield - the most acute divergences of view disclosed themselves. The widest cleavage lay between the supporters of the Joint Sitting of both Chambers and those of the Referendum, as the final means of determining a disagreement between the two Houses. The opponents of the Joint Sitting urged that the House of Commons would far outnumber the House of Lords, and that, as the result of a Joint Sitting could usually be seen in advance, those who knew that they had the ultimate majority behind them would merely smother all opposition. The Referendum was opposed upon the ground that it could not be confined merely to the settlement of disputes between the two Chambers, but that, when once introduced, it must play a dominant part in the Constitution. Its suitability for such a part was attacked by the usual arguments which have been used in previous controversies on this proposal. The failure of either section to convince the other led to a situation in which at one time the only solution seemed to be that both sides should state their views in the report of the Conference without any conclusion being reached. The final result was, however, that, after informal discussions, both proposals disappeared, and the Conference came to an agreement on the third device which had been suggested for the settlement of disputes, that of a "Free Conference." The term "Free Conference" suggests a body which confers, that is, discusses and negotiates, but has no final or binding authority. It is an accurate description of the proposal in its first form, but, as the proposal developed, it was so stiffened and magnified-largely as the result of the compromise by which the proposals for the Joint Sitting and the Referendum were both dropped - that the term is quite misleading as a definition of the scheme which eventually emerged. 
Under this scheme the proceedings of the Free Conference are to be secret. It is to consist of sixty members, thirty chosen by each Chamber. Of each half each Chamber will choose twenty members for the lifetime of the Parliament, and the remaining ten ad hoc for each particular Bill. The representatives of each House are to be chosen by the Committee of Selection of that House. A Bill on which the two Chambers cannot agree will come before the Conference at the request of either Chamber. If it is rejected by the Conference, it will die, but it may be anticipated that in most cases it will, in some form or another, come back out of the Conference to the two Chambers. The only choice they now have is to accept or reject the Bill as a whole, a point of the scheme which is fundamental, for it means that the House of Commons has finally lost control of the Bill in the form in which it was passed, and now only has before it the Bill as it has been altered by the Conference. If now both Houses either accept or reject the Bill, the matter is concluded. But, if the disagreement continues, and one House accepts the Bill while the other rejects it, there is to be a delay of one session, at the close of which the Free Conference takes it up again. If the Free Conference fails to report it back in the same form as before, it dies. But, if the Free Conference repeats it without amendment by a majority of not less than three (to ensure a substantial preponderance of opinion in its support), it then goes back to the two Houses once again. If, on this occasion, the House of Commons accepts it, it becomes law whatever may be the attitude of the Second Chamber.

The scheme is obviously a very complicated one. The first objection to it is that it lacks the simple intelligibility needed in democratic government, but its essential proposal is clear. The Free Conference can reject the Bill or can change it into any form that it decides. The House of Commons has no power in case of its rejection, and, if the Bill has been altered, even in its vital principles, must take it as it is or lose it altogether. The power of a Free Conference is, then, in the case of disputed Bills, as great as that of the House of Commons itself.

The political inventiveness of Lord Bryce and his colleagues has added one more to the possible devices by which a dispute between two Chambers can be determined, i.e., the creation of a Third Chamber which, when disagreement arises, becomes greater in power than the Second and equal in power to the First. But this fact lays bare the weakness at the heart of the whole scheme. The essential requisite, without which no Chamber could be given such tremendous powers, is that it should have an undoubted representative capacity. But the Chamber proposed is removed from the electorate by so many intermediate stages that its representative capacity is attenuated to a mere shadow. One-half is to be elected by the House of Commons ; the other half is chosen by a Chamber of which one-quarter of the members are selected by only ten persons, themselves the product of tertiary election. Of the remaining three- 
fourths, one-third will be the product of a secondary election about ten or twelve years old ; another third of a similar election six or eight years old ; and the remaining third of a similar election by a recent House of Commons. Finally, this Third Chamber is to sit in secret. A body of this kind, consisting of members holding their seats for twelve years, in the main elderly men far removed from contact with the people, publishing no division lists, but debating behind closed doors, might be suitable as a revisory assembly, with definitely restricted powers of suggestion; but the proposal to set it up as able to defeat the House of Commons is impracticable in a democratic state.

The explanation of such a proposal is to be found by tracing its development through the discussions out of which it grew. When the constitution of the Free Conference was finally carried, it had not been decided that it was to be a body of any binding authority. The amendments which transformed it into a new Chamber of enormous strength were only made at almost the last moment. But no further examination was made of its constitution, which remained as it had been before the new powers had been added. Thus, on a constitution devised for a body of very weak authority, there was finally erected a Chamber of unusual strength, founded upon a basis on which it is quite impracticable to hope that any such Chamber can stand. 